\title{
PHLS Report
}

\section{Haemorrhagic fever with renal syndrome: Hantaan virus infection}

Haemorrhagic fever with renal syndrome is a syndrome seen in diseases of varying severity which occur from the Far East across to Western Europe. The most common diseases in the Far East are Korean haemorrhagic fever and epidemic haemorrhagic fever, which are characterised by fever, muscular pains, haemorrhagic manifestations, and proteinuria; the complications of shock and renal failure may lead to death. The disease seen in Scandinavianephropathia epidemica-typifies the European disease and is much less severe, as haemorrhagic manifestations do not occur.

The first description of this disease was in 1934, when Myhrman saw 30 cases in northern Scandinavia of "nephropathia epidemica." Lähdevirta cites reports of 253 cases of the disease in Sweden, Norway, and Denmark up to 1968. An outbreak also occurred in Lapland in 1942 among Finnish and German troops. Nephropathia epidemica is characterised by an acute onset of fever with evidence of renal failure but no haemorrhagic manifestations. The usual outcome is full recovery. Lee cites references to a similar disease affecting troops stationed in Flanders during the first world war and soldiers in the American Civil War. ${ }^{3}$

Korean haemorrhagic fever is similar but has a distinct mortality. It was first described in the USSR between 1930 and 1934, where 915 cases resulted in five deaths. The disease was also reported from inner Mongolia in 1959. The syndrome attracted interest after the spring in 1951, when United Nations troops in Korea were affected. ${ }^{5}$ By the end of the Korean war a total of 3000 troops had been diagnosed as having Korean haemorrhagic fever. There were 80 deaths in the first 1000 cases, and the disease continues to be recognised in troops and civilian personnel in Korea, where there is a $5 \%$ mortality in those who are treated. Several thousands of cases have been reported from the Soviet Union, and in China there were 61705 cases in 1982 alone, again with a case fatality of $5 \% .{ }^{37}$

\section{Epidemiology}

Haemorrhagic fever with renal syndrome has an incubation period of between two to three weeks. In endemic areas the disease is most common during two distinct periods of the year-late spring and late autumn. Some infections may be subclinical. The causative agent, the Hantaan virus (named after the river in the demilitarised zone between North and South Korea), was isolated from lung tissue in the striped field mouse Apodemus agrarius ${ }^{8}$ and characterised as a member of the Bunyaviridae. ${ }^{9}$ Investigators in the 1940s in the Soviet Far East had transmitted the disease to "human volunteers" by the parenteral injection of serum and urine obtained from affected patients, while at the same time Japanese workers in Manchuria claimed to have produced the disease by the injection of bacterial free filtrates of crushed mites as well as filtrates of the tissues of the striped field mouse. Russian workers in the 1950s produced the disease by the injection of an extract of mites collected from rodents and their nests from areas known to be foci of the infection. ${ }^{+}$Hantaan virus has been isolated from rodents and cases in the Far East but not from cases in Scandinavia and Europe.

The virus appears to produce a range of disease ranging from severe in the Far East, China, and parts of the USSR to a mild nephropathy in Scandinavia, the western USSR, and Europe. Several serotypes have been identified. Evidence of infection by
Hantaan virus has been found in wild rodents in the East and in voles in Europe. ${ }^{10-12}$ Domestic rats in Korea have been shown to be a reservoir of the virus. ${ }^{3}$ Infection of wild rodents with an antigenically similar agent has been reported in the United States. ${ }^{13}$

Serological surveys have found evidence of human infection not only in countries of the Far East, Eurasia, and Scandinavia but also in France, Belgium, Greece, and Yugoslavia ${ }^{10111+21}$; acquisition of antibody after infection appears to be lifelong. ${ }^{3}$

The exact mode of transmission of the viruses to humans is probably through contact with aerosols from the lung, saliva, or urine of infected animals. There are three epidemiological types': rural, urban, and laboratory.

In Western Europe the rural type presents in people living or visiting rural areas either as military personnel or by virtue of their occupation such as fishing, hunting, logging, or railroad work. In 1971 Lähdevirta reported 380 cases of nephropathia epidemica in Finland, ${ }^{2}$ and cases occurring in Sweden between 1959 and 1975 were reported in $1977 .{ }^{22}$ In the Finnish report $95 \%$ of patients were from rural areas, and in Sweden the highest incidence of the disease was in sparsely populated parts of the country. The overall incidence in the northern area of Sweden was 0.08 cases per 1000 inhabitants a year with men affected nearly four times as often as women. The Finnish series comprised $80 \%$ men, and the highest incidence was among farmers aged 20-40. During the time of the reported investigation in Sweden the disease was found to be cyclical in small rodents and seasonal in humans. The variations in the two phenomena were found to coincide, and in Finland the highest incidences seemed to coincide with years of a high prevalence of voles. Cases associated with rural rodent contact and other sporadic cases are now being reported from France and Belgium. . $3-29^{-29}$

In the urban type the reservoir is the domestic rat; this variety is fairly common in city areas of South Korea and Japan.

Infections, both clinical and subclinical, acquired from animals in laboratories, have occurred in laboratory workers in Korea, Japan, ${ }^{3}$ France, ${ }^{29}$ and Belgium. Laboratory acquired infection has been documented in at least one institution in England. Imported rats may have been responsible for transmission to staff in this laboratory between 1975 and $1979 .{ }^{3031}$ A 21 year old man from Scotland, who had not been abroad before his illness in August 1983 , was the first documented case acquired in the community in Britain.

Public Health Laboratory Service Communicable Disease

Surveillance Centre,

London NW9 5EQ

\section{References}

1 Myhrman G. Nephropathia epidemica: a new infectious disease in northern Scandinavia. Acta Med Scand 1951;140:52-6.

2 Lähdevirta J. Nephropathia epidemica in Finland. Ann Clin Res 1971;3(suppl 8):1-154

3 Lee HW. Korean haemorrhagic fever. In: Melnick JL, ed. Progress in medical virology. Vol 28. Basle: Karger, 1982:96-114.

Earle DP. Foreword. Am $\mathcal{f}$ Med 1954;16:617-8.

5 Smadel JE. Epidemic haemorrhagic fever. Am f Public Health 1953:43:1327-30.

6 Lee HW, I.ee PW, Johnson KM. Isolation of the etiologic agent of Korean hemorrhagic fever. Infect Dis 1978;137:298-308.

7 Gan S, Chang-Shou H, Hua-Xin L, Jian-Lin F. Antigenic comparison of virus strains of mild and classical types of epidemic haemorrhagic fever isolated in China and adaptation of these to cultures of normal cells. Lancet 1984;i:677-8.

8 World Health Organisation. Haemorrhagic fever with renal syndrome. World Health Organisation Weekly Epidemiological Record 1982;57:217-8. 
9 Schmaljohn CS, Hasty SE, Harrison SA, Dalrymple JM. Characterisation of Hantaan virions, the prototype virus of hemorrhagic fever with renal syndrome. $\mathcal{F}$ Infect Dis 1983;148:100512.

10 Lee HW, Lee PW, Lähdevirta J, Brummer-Korvenkontio M. Aetiological relation between Korean haemorrhagic fever and nephropathia epidemica. Lancet 1979;i:186-7.

11 Lähdevirta J, Enger E, Hunderi OH, Traavik T, Lee HW. Hantaan virus is related to haemorrhagic fever with renal syndrome in Norway. Lancet 1982;ii:606.

12 van der Groen G, Tkachenko EA, Ivanov AP, Verhagen R. Haemorrhagic fever with renal syndrome related virus in indigenous wild rodents in Belgium. Lancet 1982;ii:110-1.

13 Lee PW, Amyx HL, Gajdusek DC, Yanagihara RT, Goldgaber D, Gibbs CJ. New haemorrhagic fever with renal syndrome-related virus in indigenous wild rodents in United States. Lancet 1982 ;ii: 1405 .

14 Svedmyr A, Lee HW, Berglund A, Hoorn B, Nystrom K, Gajdusek DC. Epidemic nephropathy in Scandinavia is related to Korean haemorrhagic fever. Lancet 1979; 100.

15 Lee PW, Gibbs CJ, Gajdusek DC, Hsiang CM, Hsiung GD. Identification of epidemic haemorrhagic fever with renal syndrome in China with Korean haemorrhagic fever. Lancet 1980;i:1025-6.

16 Svedmyr A, Lee PW, Gajdusek DC, Gibbs CJ, Nystrom K. Antigenic differentiation of the viruses causing Korean haemorrhagic fever and epidemic (endemic) nephropathy of Scandinavia. Lancet 1980;ii:315-6.

17 Lee HW, Antoniadis A. Serological evidence for Korean haemorrhagic fever in Greece. Lancet $1981 ; 1: 832$.

18 Lee, PW, Svedmyr A, Gajdusek DC, Gibbs CJ, Nystrom K. Antigenic difference between European and East Asian viruses causing haemorrhagic fever with renal syndrome. Lancet $1981 ;$ ii:256-7.
19 Tkachenko EA, Donets MA, Rezapkin GV, et al. Serotypes of HFRS (haemorrhagic fever with renal syndrome) virus in East European and Far Eastern USSR. Lancet 1982;i:863.

20 Anonymous. Muroid virus nephropathies [Editorial]. Lancet 1982;ii:1375-7.

2.1 Lee PW, Goldgaber D, Gibbs CJ, et al. Other serotypes of haemorrhagic fever with renal syndrome viruses in Europe. Lancet 1982;ii:1405-6.

22 Nystrom K. Incidence and prevalence of endemic benign (epidemic) nephropatiny in AC County, Sweden, in relation to population density and prevaience of small rodents. Acta Med Scand [Suppl] 1977;609:1-92.

23 Méry J-P, Dard S, Chamouart J-M, et al. Muroid virus nephropathies. Lancet 1983;ii:845-6.

24 Dournon E, Brion N, Gonzalez JP, McCormick JB. Further case of haemorrhagic fever with renal syndrome in France. Lancet 1983;i: 1419

25 van der Groen G, Piot P, Desmyter J, et al. Seroepidemiology of Hantaan-related virus infections in Belgian populations. Lancet 1983;ii: 1493-4.

26 van Ypersele de Strihou C, Vandenbroucke JM, Levy M, et al. Diagnosis of epidemic and sporadic interstitial nephritis due to Hantaan-like virus in Belgium. Lancet 1983;ii: 1493.

27 Chanard J, Melin J-P, Milcent T, et al. Focus of muroid virus nephropathy in France. Lancet 1984;i: 98.

28 Dournon E, Moriniere B, Matheron S, et al. HFRS after a wild rodent bite in the HauteSavoie-and risk of exposure to Hantaan-like virus in a Paris laboratory. Lancet 1984;i:676-7.

29 De Ligny BH, Prieur JP, Schmitt JL, et al. Ten new cases of HFRS in north-eastern France. Lancet 1984;ii:864-5.

30 Lloyd G, Bowen ETW, Jones N, Pendry A. HFRS outbreak associated with laboratory rats in UK. Lancet 1984;i:1175-6

31 Anonymous. Current notes: Hantaan-like virus infection. Communicable Diseases Scotland Report 1984;29:vii

\title{
Philosophical Medical Ethics
}

\section{Utilitarianism}

\author{
RAANAN GILLON
}

There is something very attractive about the straightforward idea that morality is all about maximising happiness and minimising misery: that one's actions are right insofar as they tend to that end, wrong insofar as they tend to decrease happiness or increase misery and morally neutral insofar as they tend to do neither. This idea, encapsulated in the Benthamite slogan "the greatest happiness of the greatest number," is the basis of all utilitarian theories of ethics, which, though they have their origins at least as early as Epicurus, were developed by Bentham, Sidgwick, and Mill in the 18th and 19th centuries and have been elaborated and refined extensively by a variety of recent philosophers.

In my last article I discussed several sorts of ethical theory that reject the premise that ethics can be reduced to considerations of the consequences of actions, notably their effects on overall happiness and misery. Whether or not these considerations should be a necessary part of an adequate theory of ethics, the common theme of what I called deontological theories was that they were certainly not sufficient. Some of these theories, notably Kant's, were, like utilitarianism, monist theories in that they relied (or purported to rely) on a single moral principle. Others-pluralist theories-relied on more than one, potentially conflicting, fundamental moral principle. Moreover, some were absolutist theories in that at least one moral principle was held to apply categorically and without exception while others were non-absolutist in that the principles were, as Ross put it, prima facie.

At first sight medical ethics, as reflected in the codes of such bodies as the World Medical Association, seem to fit well into an absolutist deontological ethical system for they contain some moral

Imperial College of Science and Technology, London SW7 INA

RAANAN GILLON, MB, MRCP, director, Imperial College health service, editor of fournal of Medical Ethics, and associate director, Institute of Medical Ethics rules that apply without exception and that explicitly or implicitly reject considerations of overall happiness and suffering. For instance, the Declaration of Tokyo categorically rejects doctors taking part in torture. Some medical practitioners, on the other hand, see medical ethics as being basically utilitarian, ${ }^{1}$ sometimes ruefully. ${ }^{2}$

In the rest of this article I shall try to outline the pros and cons of utilitarianism. Whether one ultimately accepts the theory (and I am inclined to reject even the most attractive version) it is important to understand (1) that utilitarianism has become a complex cluster of moral theories based on the principle of maximising welfare and that simplistic criticisms based on simplistic accounts of the theory are inappropriate and (2) that contemporary utilitarianism in several of its variants purports to encompass the ordinary prima facie "deontological" moral principles used in everyday moral and medicomoral decision making.

\section{Advantages claimed for utilitarianism}

Utilitarianisn claims to overcome four major disadvantages of what I have called deontological moral theories. These are:

(1) The reliance on moral intuitions to identify moral principles notwithstanding the variability and unreliability of such intuitions. (For thousands of years intuition led people to accept slavery as being morally defensible.)

(2) The pluralism of many deontological theories, whose moral principles may conflict.

(3) The absolutism of more than one principle in some pluralist theories. If these principles apply without exception any conflict between them must be irreconcilable.

(4) Typically, the lack of a consistent and reliable decision procedure for choosing the right course of action in particular circumstances.

Utilitarianism purports to overcome these major defects in 